\title{
LXXV. Prospectus of a new system of beaconing
}

\section{Robert Dickinson}

To cite this article: Robert Dickinson (1817) LXXV. Prospectus of a new system of beaconing , Philosophical Magazine Series 1, 50:236, 443-449, DOI: $10.1080 / 14786441708637815$

To link to this article: http://dx.doi.org/10.1080/14786441708637815

曲 Published online: 27 Jul 2009.

Submit your article to this journal $x$

III Article views: 2

Q View related articles $₫$ 
I shall close this long letter, by observing that on casting my eye over the configuations of Jujitcr's satellites for the month of January, I find the position of almost all of thens to be erroneous. İ am, sir,

\section{Your obedient servant,}

Astrononicus.

P. S. - In the preface to the Nautical Almanac it is stated that "all the articles were computed by two separate persons, and examined by a third:" perhaps it may exercise the ingenuity and abilities of some of your readers, to determine the probalility that three persons should commit precisely the same mistake in any calculation; and that a repetition of similar errors should occur several times in a work of 144 pages!!!.

LXXV. Prospecius of a new System of Beaconing. By His Majesty's Royal Letters Paient granted to Robert Dickinson, Great Queen-Streel, London.

T

HERE is something so new in this Prospectus, and the benefits to be expected from the alophion of the system it recommends are so many and so importaut, that we cannot too earnestly recommend it to the atiention and speedy adoption of those who from their situation possess the means of giving efficacy to any plan calculated to benefit the intcrests of navigation and humanity. Induced by the statements in the Prospectus to examine for ourselves the models of the pntenter, we waited on the inventor, and bestowed on them a very careful inspection; and we have no hesitation in stating that, in sur opinion, the system is quite scientific, and so pertect as to leave little or nothing to. be desired, but its speedy and miversal adoption by the coamon consent ind patronage of all the maritime powers.-EDat.

\section{prospectus.}

The design of this Prospecius is to propose a new heacon, of the following description and uses, with a view to beaconing the seas of the world.

lst. Rvery bescon on this construction will tell the longitude, latitude, soutdings, hearings, and distance from land; how to be approalsed, currents, \&e. with every other particular which the moit elaborate and correct survey can describe.

2mly. Every heacon, and the particulars belonging thereto, will be as well known and as familiar to navigators of the remotest clines, aud of all nations, as to those of its own country.

$3 \mathrm{dly}$. It presents the figure of an erect pillar (see the Plate), and can be placed in all tathomable depths of any reasonable size and elevation, say from 6 to 18 or 20 feet in height. 


\section{4}

Prostectus of a new System of Beaconing.

4 thly. It will always be found preciscly in the spot where it was first laid down.

5 thly. Being erect, it can be seen at a much greater distance than the present buoy.

6thly. It will remain completely water-tight.

7thy. While it deties alike the raging tempest, the fields of ice, weeds, the shock of a first-rate man of war, or any other body with which it may be assailed; that of the ordinary size is so reed-like and yielding, that the smallest jolly-boat would not, if suffered to run against it, be in the least injured.

8thly. Lastly, perhaps not least to be regarded, (as it may tend to its being more disseminated over the ocenn and different seas,) it can be put down at a small expense; and, incredible as the foregoing may appear, the patentee (after me month's preparation) will engage to furnish twenty beacons a weels with all their appenciages, and send to any quarter of the globe*.

To show how the superiority now described is effected, the following observations are offered :-It consists, lst and principally, in the singularity of its shape, which is not very unike that of a shoulder of mutton before the sharik is cut off. 2 dly, In the systematic arrangements respecting its moorings; aud, $3 \mathrm{dly}$, In its speaking an univeral language.

in giving the borlies intended for sea beacons the form of a cone, (as has always been dont,) a great error was committed, as no shape affording so much iesistance, and therefore so badily calculated for the passing of the water, could lave been found. The next error was, in loaking this ill-formed body, which ought to have been as light as possible, with a trenendons heavy chain. Poth these evils are here avoided, the shatpe offered being much shurper in the water than the sharpest Thumes wherry; and not being loaded by the cluan, as will be shown, the resistance is much less than that of a whery, and it rides considerably lighter in the water.

The annexed engraving will convey some idea of the improved form triven to this beacon: which also, in what regards flontage, presents, it is presnmed, a new practical principie, and which, the patente is vain enough to imagine, will be thought to possess consulerable novelty, as hitherto the effect now jroduced, viz. the ficating of a pillar, has never, that he knows of, been acconplished, without the very ohjectionable incumbrance of an enornious bulk, and a cuantity of countejpoising ballast, proportioned to the elevation of the objest to be raised. Indeed, it is hardly credible, after the numberless impreroments that have been in-

* Corponte bodies, and such indiriduals as desire to see the models, with their description, will be pleased to apply by letter, addressed "To the l'atentee, 58, (ircat Queen-street."

troduced 
troduced into nautical science, that the beacon should have reraained, for so many centuries, in a state so defective, seeing as one does (vide Lloyd's List) that more casualties and shipwrecks are occasioned by getting aground, (which beacons are intended as, and perhaps are, the only means of preventing, than from any or all other couses united.--Hence, it is a duty incumbent on mankind generally, to endeavour to render this system perfect, or as nearly so as cun be attained by human invention, by human assiduity, and by an accordance of sentiment in all the maritime nations of the world; and, seeing that the benefit to the human race and the advantages of such a union would be reciprocal, it cannot fail, soon or late, of being carried into effect.

The part of the beacon represented out of water, is a pillar, of three or four equal sides, on each of which is painted the same number, whether it be one or one thousand, in such a nanuer that, when the units are exceeled, the figures must be written

\section{$1 \quad 1 \quad 9$}

dowwwards: 10 thus, $0:-15$ thes, $5:-999$ thus, $9:-$ and, from the form of the pillar, it is difficult to take any position in which the figures will not on one side be seen and distingasished at $\left.\right|_{\mid}$consideralyle distance; and ships beyond reading distance, if they want intormation, will approach nearer to obtain it.

A Beacon Book, or Formula of References, is to he printed in various languages, whereili will be laid down, by means of corresponding numbers, all the particulars relating to every beacon, and which book, when referred to by the bewildered mariner meeting with a beacon, will, of course, instantly acquaint him with his situation, tire dangers and diffeulkes by which he is surrounded, \&c. \&c.*

A writer in the American Philosophical Transactions touly remarks, that "the duties of a buoy (meaning a beacon) are most imperious; to the performance, however, of which, it is lamentable to reflect, from their construction and appsintment, they are wholly incompetent; for, in fact, all they teli is'Hereabouts is danger;' but on what side, or to what extent, the bewildered stranger is left to guess and find out." And, in truth, it would be difficult for the imagination to conceive an idea of any thing so rude, shapeless, ill-chosen, and unmeaning. as the canin-buoy, the present beacon, as it is called.

* To say any thing wespecting the mode of distributing such books, wouid at present be premature. Those with whom it nust lie, to give efficary to the system, will be at no loss to give them circulation by means of the Custom-houses whence vesscls are cleared out for sea. 
" But (it may be objected) is it to be expected that all the nations of the earth can be brought to concur in the establishment of such a system ?"- - To this it may be answered, that, all having an obvious interest in such establishment, it is not un. reasonable to believe, that every civilized state may be easily induced to lend its aid to the perfecting of a plan which promises so many benefits to the human race generally. In the mean time, it is consoling to humanity to know, that, among ourselves, there is no want of either heads or hearts to patronize and cherish any rational plan, which has for its object the saving of the lives of thousands of our fellow-creatures (now sacrificed to a system left defective, merely bccause the possibility of a remedy was not contemplated; and adding much to the comfort and happiness of all who are doomed to traverse the ocean. The Right Honourable the Lords of the Admitalty, the Minister for the Foreign Department, the Brethren of the 'Trinity House, are sufficient to call it into attion without any forcign concurrence. On our own coasts there is much occasion for it; nor can it be reasonably doubted, that, meeting with the countenance of our own Govermment, most of the European maritime powers, and also the United States, would easily be induced to lend a hearty co-operation.

In fivour of any exertion that may be made for establishing a general system of Beaconing; it is to be remarked, that the contrivance already alluded to, of employing buoys attached to different parts of a chain (see the engraving), to act as carriers, besides furnishing a means for planting beacons in comparatively deep seas, is calculated to promote the undertaking by the facilities which it afords in point of expense. The chain, as already stated, may be very small; for each carrier luars its ou'n portion of $i$, and the ultimate strength wanted is only what may he required to withstand the current (when there-is sue) and the wind; neither of which can ever exerrise any power upoti the beacon, at all to be compared with what is now required to sustain a common beacon chain * The beacon itselt thas nothing to carry but a few links of that portion by which it is united to the upper carrier; and from its form, and the material of which it. is made, (viz. inetal $\uparrow$,) suffers any vessel or other floating body

* The strength recuircd when only the strain occasioned by wind and current is to be provided agrinst, is much less thin most people would inagine. In an cxperiment made at sea, of Sonthend, in twelve-fathom water in a very high wind, a piece of common jack-chain (unable to sustain two hundred weight without breaking) was found perfectly adequate to keep a beacon exposing six feet of height above the surface, in its place, the chain being borne by three carriers.

$t$ Experience has shown that wood, as a material, is but ill adapted for marine 
body which may come in contact with it, to pass, without any other effect than moving it to one side, or passing over it ; after which, it will instantly recover its position, aud perform its duty as before; so that the expense of maintenance will be trifling. Nor is the saving in weight (which in every case will be at least 80 per cent.) the only benefit that results from the use of carriers: the greater part of the expense of manufacture can also be dispensed with, straight rods linked to each other at their ends, ansivering as well as the most expensive chains.

The advantages which will present themselves to the minds of those acquainted with nautical matters, as likely to result from this system, must be manifold beyond any thing that the author (who is no sailor) can conceive ; but one thing is obvious, that it must prove highly beneficial that these beacons (instead of rolling about like so many porpoises, scarcely visible,) are always standing erect, exhibiting a height of from six to twenty feet above the surface, and may be seen to intercept the line of the horizon at several miles distance.

Nor is the proposed system applicable to shallows only. As it provides means for sustaining chains of any length, it is now possible to plant beacons in any seas that cau be somuded. And it deserves particular notice, that the method which has been devised for sustaining chains, however heavy, proves at the same time, a means for rendering chains that are comparatively light, able alike now to perform all that duty which formerly required very heavy and strong chains. Nay, more: light chains can now be made to perform what could not he done at all formerly ; for in proportion to the depth, so it was then necessary to increase the strength, not merely to enahle the chain to restraiu the buoy, unnecessarily bulky, \&c. and improperly loaded, but cren to sustain its own weight *. From this circumstance, the utmost depth that could

marine beacons. It is apt to admit water, and need tapping, easily daw maged by worms, subject to rapid decay, and but ill suiced to be workęd into the best form for a beacon. The patentee has adopted iron, as a material subject to none of these onjections, being homogeneous, impervions to water and worms, and expanding or contracting equibly in all its parts, when exposed to changes of temperature. Shoulu it be oljected that iron will soon be destroyed by rust, it is answered, The pateited has a method of coating his iron, so as to defend it for a gueat number of years; as is proved by some beacons fumished by him for Government, and which have been for a considerable time in use at the Island of Berutuda.

* The common beacon, having a great weight to corry, is necessarily obliged to be made very balky; and in consequence, there is a constant struggle between the bioy and the chain at the passing of every wave; by which repeated tugging action, the block to which the other end of the chain is made fast, is, by incumerable and constantly repeated hitches, gram dually removed from its pluce, sometines a mile or two; an event that 
he reached was, comparatively, very limited; no means being known before, whereby it could be accomplished. The thing, however, is now practicable; and, sooner or later, it will be ef s fected ; for it is equally rational that the seas should be furnished with navigation-posts, as that travellers by land should have the convenience of mile-stones and finger-posts provided for them*.

Tha Star Newspaper, of the 20th of Septemler 1817, contuins the fullowing Extract of a Letter from Derry.

\section{"SHIPWIRCK.}

"Ferry Side, Carmarthen, September 26th, 4 p.s.

"I am sorry to inform you, that at about four miles distance, a brig with yellow sides, and about two hundred tons burthen, has got on a point of sand : her masts are gone overboard, and she must be a total loss, as the wind is strong from the S.W. with a heavy sea :-a boat is observed full of men, going into Kidwelly; but whether it is the crew of the vessel, or some men intending to go to her assistance, we are unable to ascertain.

"Seven o'clock, P.M. The tide is now on the turn, not a vestige of the vessel is to be seen, she totally disappeared about an hour ago, and our opinion is, that the captain is a stranger on our coast."

It does not follow, because the present system is of great antiquity, enornonsly expensive, and has been got up with wonderful and praise-worthy labour and attention, that it is complete; nay, that it is not most lamentably defective, as, indeed, we know it to be, from the melancholy accidents arising almost daily from the single circumstance of getting aground:-The pains which have been taken, only prove that the necessity for doing something was so urgent, that something must be done, and the best has been done that happened to be thonght of. Nevertheless, were this system under the exclusive control of one individual, it would not be surprising to find him clinging to it, for no other reason but because it was old, laboured, and expensive; but under the enlightened management of a corporate body, like that of the Trinity House, composed as it is of talent and respectability, which true merit alone can influence, defent aud delay on this occasion are not to be apprehended. The present proposal

never can occur with the telegtaphic or pillar beacon, which having no belly above the water lint, is not affected by the waves; and having only its own fastening to carry, requires from the block and its chain no mo:e than simply to resist the curreat; a pressure to which the strength of one man is more than equal. The consequence of a beacon changing its situation is, that it changes also its character, and instead of heing the mariner's beacon and friend, becomes a deceiver, and a decoy to his destruction.

* The summits of the new beacon are made conical and sharp pointed, to prevent birds from resting on them, and obliterating the figures. 
will no doubt be scrupulously examined; and, if found worthy, adopted. The expense will not then be thrown away upon a system comparatively worthless, and which has been submitted to, only for want of possessing better means: and when the system now recommended shall have become general, there will be no longer "strange captairs on any coast:" and alsc it should be considered, that as the light expense at which it can be carried into effect will allow an increase of beacons, (it is thought of nearly ten to one,) the security will be increased in a tenfold ratio, independent of the duty being so much better performed.

LXXVI. Notices respecting New Books.

The Second Part of the Philnsophical Transactions of the Royal Society of London, for 1817, has just been publislied, and contains the following pajers:

XIII. Description of a thermometrical Barometer for measuring Altitudes. By the Rev, Francis John Hyde Wollaston, B.D.F.R.S.-XIV. Observations on the Analogy which subsists between the Calculus of Functions and other Branches of Analysis. By Charles Babbage, Esq. M.A.F.R.S.-XV. Of the Construction of Logarithmic Tables. By Thomas Knight, Esq. Communicated by Taylor Combe, Esq. Sec. R.S.-XVI. Two general Propositions in the Method of Differences. By Thomas Knight, Esq. Communicated by Yaylor Combe, Esq. Sec. R.S. -XVII. Note respecting the Demonstration of the binomial Theorem inserted in the last Volume of the Philosophical Transactions. By Thomas Knight, Esq. Communicated by Taylor Combe, Esq. Sec. R.S.-XVII. On the P'assage of the Orum from the Ovarium to the Uterus in Women. By Sir Everard Home, Bart. V.P.R.S.-XIX. Some further Observations on the Use of Colchicum autumnale in Gout. By Sir Everard Home, Bart. V.P.R.S.-XX. Upon the Extent of the Expansion andContraction of Timber in different Disections relative to the Position of the Medulla of the Tree. By Thomas Andrew Kuight, Esq. F.R.S. In a Letter addressed to the Right Hon. Sir Joseph Banks, Bart. G.C.B.P.R.S.-XXI. Observations on the Temperature of the Ocean and Atmosphere, and on the Density of Sea-water, made during a Voyage to Ceylon. In a letter to Sir Humphry Davy, LL.D. F.R.S. By John Davy, M.D.R.R.S. -XXII. Observations on the Genus Ocythoë of Rafinesque, with a Description of a new Species. By William Elford Leach, M.D.F.R.S.-XXIII. The distinguishing Characters between the Ova of the Sepia, and those of the Vermes testacea, that live in Water, explained, By Sir Everard Home, Bart. V.P.R.S.XXIV. Astronomical Observations and Experiments tending to investigate the local Arrangement of the celestial Bodies in Space,

Vol.50. No.236. Dec. 1817.

F f

and 